\title{
The influence of ethephon application to processing tomato plants on yield structure in relation to weather conditions during the growing period
}

\author{
Eläbieta Jędrszczyk ${ }^{1 *}$, Barbara Skowera ${ }^{2}$, Renata Kędzior ${ }^{2}$, Maria Gawęda ${ }^{1}$ \\ ${ }^{1}$ Department of Vegetable and Medicinal Plants \\ University of Agriculture in Kraków \\ 29 Listopada 54, 31-425 Kraków, Poland \\ ${ }^{2}$ Department of Ecology Climatology and Air Protection \\ University of Agriculture in Kraków \\ Mickiewicza 24/28, 30-059 Kraków, Poland
}

\begin{abstract}
The aim of the study was to evaluate the effect of ethephon application (Agrostym 480 SL) on the yield and yield structure of five processing tomato cultivars (Rumba, Hubal, Sokal $\mathrm{F}_{1}$, Mieszko $\mathrm{F}_{1}$ and Polset $\mathrm{F}_{1}$ ). The experiment was carried out in the open field in the years 2009-2011 in Mydlniki near Kraków, Poland. Two weeks before harvesting, half of the plants of each cultivar were treated with Agrostym $480 \mathrm{SL}\left(3 \mathrm{dm}^{3} \mathrm{ha}^{-1}\right)$ and the other half were left as a control without spraying. Marketable yield included properly shaped and welldeveloped light red and red fruits. Non-marketable yield included pink and turning fruits, mature green and breaker fruits, and diseased fruits. A generalized linear model (GLM) for Poisson distribution with the log link function was used to determine the relationship between the years of the study and cultivar and selected values of the yield structure. The yield structure of tomato depended significantly on the weather conditions during the growing period in different years of the study, on the cultivar, and on the use of ethephon. Ethephon had a particularly beneficial effect on yield structure in the years with an unfavourable distribution of precipitation. Ethephon application in the years 2009 and 2010 had a beneficial effect on the health of tomato plants.
\end{abstract}

Key words: Agrostym 480 SL, cultivar, diseased fruits, mature-green fruits, turning fruits, red fruits

\section{INTRODUCTION}

Tomatoes are one of the most widely produced and consumed vegetables in the world. The yield of this thermophilic and disease-susceptible plant is largely dependent on weather conditions (Jędrszczyk et al. 2012, Skowera et al. 2014). A well-chosen cultivar and proper field crop production affect tomato yield efficiency. To achieve success in field cultivation of tomato, producers should select early cultivars, which are better able to reach full maturity in the field. This is emphasized by Kenavy et al. (2008), who state that the short growing season at higher geographical latitudes limits the number of cultivars used for field cultivation, and the choice of an early-maturing cultivar is a factor making it possible to overcome climatic limitations.

One problem in field cultivation of tomato may be uneven colouring of the fruit. During the ripening process tomato fruits pass through the 
following stages: mature green, breaker, turning, pink, light red and red (Saltveit 2005). Tomatoes for processing are harvested mechanically, when about $90 \%$ of the fruit on the plant is mature, and therefore concentrated ripening of tomato fruit is an important trait in the cultivation of processing cultivars. Unfortunately, during fruit maturation in summer the weather is quite often unfavourable. In this situation it is possible to achieve a profitable marketable yield by applying preparations from the group of growth regulators containing ethephon. Ethephon is an aqueous formulation that decomposes to ethylene, a phytohormone that controls or influences many aspects of plant growth and development (Liptay et al. 1981, Gonzales 1999, Saltveit 1999). Climacteric fruits, which include tomatoes, require an increase in ethylene biosynthesis at maturity in order to ripen (Moniruzzaman et al. 2015). Therefore, in field crop production of processing tomato cultivars preparations enhancing fruit maturity and increasing marketable yield are often applied.

Agrostym $480 \mathrm{SL}$ is designed to advance harvesting and improve fruit ripening in tomato grown in the open field. The active ingredient in Agrostym $480 \mathrm{SL}$ is ethephon. In the plant tissue, where the $\mathrm{pH}$ is higher, it is decomposed to a compound called ethylene. The role of ethylene is to activate transcription of certain genes associated with ripening processes and at the same time to regulate mRNA translation of some proteins. Acceleration of fruit ripening by using agents such as Agrostym $480 \mathrm{SL}$ is profitable on properly cultivated plantations with well-developed plants which have produced a large quantity of fruit. Products containing ethephon must be applied at the appropriate stage of plant growth.

Fruits of tomato plants treated with ethephon are harvested 2-6 days earlier. The harvest window is significantly reduced as well (Logendra et al. 2004, Moniruzzman et al. 2015).

In tomato cultivation, the recommended application rate of Agrostym $480 \mathrm{SL}$ is $2-3 \mathrm{dm}^{3}$ $\mathrm{ha}^{-1}$ and the preferred amount of water is 600$1,000 \mathrm{dm}^{3} \mathrm{ha}^{-1}$. For plants with a large leaf mass and during a colder period when the temperature falls below $16^{\circ} \mathrm{C}$, it should be applied at the higher of the recommended rates. In the climate conditions of Poland, such temperatures may occur in the second half of August and in September, when late tomato cultivars are maturing. The effectiveness of Agrostym 480 SL increases with air temperature, and it is most effective at $20-25^{\circ} \mathrm{C}$.
Plants are sprayed once, and this should be done when the fruits are already at full size, with pink and turning fruit accounting for $5-15 \%$ and mature green fruit for $50-70 \%$ of all the fruit on the plants. It should be remembered that ethephon does not have an effect on small fruits and also that too high a concentration may cause several side effects, including rapid and extensive defoliation (Kevany et al. 2008). Farag and Palta (1993) emphasize that ethephon application causes leaves to age faster, which facilitates mechanical harvesting of fruit. On the other hand, the loss of foliage may lead to faster overripening and sunburn of tomato fruits, particularly during a hot summer. Acceleration of ripening with ethephon affects the chemical composition of fruit (synthesis of sugars and organic acids, flavour and aroma), as well as yield structure (Kenavy et al. 2008, Payasi and Sanwal 2010, Dhall and Singh 2013). Many authors also emphasize the varied responses of different cultivars to the use of ethylene (Orłowski et al. 2005, Dobromilska and Kujath 2006, Kevany et al. 2008).

The aim of the study was to evaluate the effect of ethephon application (Agrostym 480 SL) on the yield and yield structure of five processing tomato cultivars.

\section{MATERIAL AND METHODS}

The experiment was carried out in the years 2009-2011 on a brown soil at the Experimental Station of the Department of Vegetable and Medicinal Plants in Mydlniki, near Kraków, Poland. Meteorological elements, i.e. air temperature and precipitation totals, were monitored on the experimental plots. Five cultivars of determinate tomato were included in the study; Polish cultivars: Rumba and Hubal (Reguły Breeding), Sokal $F_{1}$ and Mieszko $F_{1}$ (PlantiCo Breeding) and the Dutch cultivar Polset $F_{1}$ (Bejo Zaden Breeding). Rumba, Sokal $F_{1}$, Mieszko $F_{1}$ and Polset $F_{1}$ are early cultivars that come into full fruiting after 70-75 days from planting. Hubal is a later maturing cultivar that reaches the full ripening period 10 days later (after 80-85 days). Six-week-old seedlings were planted at $80 \times 60 \mathrm{~cm}$ at different times each year, depending on weather conditions - 21.05.2009, 29.05.2010 and 16.05.2011. The experiment was set up as a split-block design with four replications. The effect of cultivar and ethephon application (Agrostym 480 SL) was investigated. The basic soil fertilization was adjusted based on the results of soil analysis, the available forms of mineral constituents being supplemented to the level of 
Table 1. Mean monthly air temperature, total precipitation and number of days with precipitation during the 2009-2011 growing period in relation to the long-term average from 1981-2010

\begin{tabular}{lcccccc}
\hline Meteorological elements & Years & May & June & July & August & September \\
\hline \multirow{3}{*}{ Mean temperature $\left({ }^{\circ} \mathrm{C}\right)$} & $1981-2010$ & 14.0 & 16.8 & 18.8 & 18.2 & 13.5 \\
& 2009 & 13.5 & 16.0 & 19.9 & 18.7 & 15.1 \\
& 2010 & 12.8 & 17.5 & 20.7 & 18.4 & 12.1 \\
& 2011 & 12.7 & 17.6 & 20.9 & 18.8 & 12.4 \\
\hline \multirow{2}{*}{ Total precipitation (mm) } & $1981-2010$ & 81.0 & 87.0 & 88.0 & 77.0 & 63.0 \\
& 2009 & 97.8 & 140.2 & 82.6 & 53.1 & 35.0 \\
& 2010 & 299.0 & 135.1 & 105.2 & 127.5 & 116.3 \\
Days with precipitation (No.) & 2011 & 223.0 & 122.0 & 110.4 & 138.2 & 92.4 \\
\hline & $1981-2010$ & 12 & 12 & 13 & 11 & 10 \\
& 2009 & 17 & 21 & 15 & 10 & 11 \\
\end{tabular}

$120 \mathrm{mg} \mathrm{dm}^{-3} \mathrm{~N}, 80 \mathrm{mg} \mathrm{dm}^{-3} \mathrm{P}, 250 \mathrm{mg} \mathrm{dm}^{-3} \mathrm{~K}$ and 80 $\mathrm{mg} \mathrm{dm}{ }^{-3} \mathrm{Mg}$. The plots were weeded mechanically, as needed. During the growing seasons chemical disease control was carried out in accordance with the Plant Protection Programme. Irrigation was carried out only in 2009 to supplement the precipitation needs. Sprinkle irrigation was applied supplying $12 \mathrm{~mm}$ of water in June and July, and 22 $\mathrm{mm}$ in August.

Two weeks before harvesting, half of the plants of each cultivar were treated with Agrostym 480 SL $\left(3 \mathrm{dm}^{3} \mathrm{ha}^{-1}\right)$ and the other half were left as a control without spraying. Fruits were harvested on 7.09.2009, 14.09.2010 and 30.08.2011. The earlier harvest in 2011 was dictated by a forecast drop in temperature and by rainfall. All of the fruits were harvested from the plots, including those that were not yet ripe. Marketable yield included properly shaped and well-developed light red and red fruits. Non-marketable yield included pink and turning fruits, mature green and breaker fruits, and diseased fruits.

Weather conditions were monitored during the experiment. The meteorological characteristics of the tomato vegetation period were based on three main elements:

- temperature of the air, being the resultant of the heat balance (sensible heat),

- sum of precipitation representing the revenue side in the water balance,

- number of days with precipitation, characterizing the time distribution of precipitation.

Air temperature was recorded with $\mathrm{HOBO}$ Data Logger sensors (produced by Onset Company
Corporation, USA) at the standard height of $2 \mathrm{~m}$, and precipitation was measured with a Hellmann rain gauge at the standard height of $1 \mathrm{~m}$. The data were compared with the long-term averages from the nearby station at Kraków-Balice.

The years of the study were highly varied in terms of temperature and precipitation (Tab. 1). The conditions in the year 2009 were the most similar to the long-term average. In the years 2010 and 2011 the precipitation totals registered on the experimental plots substantially exceeded the average for the region. In the year 2010, due to heavy and frequent rainfall in May $(302 \mathrm{~mm}$ of precipitation), the plants could not be planted on schedule. Moreover, the amount of rainfall in August of that year was nearly twice the average, which impeded correct and timely plant protection procedures.

The Shapiro-Wilk test (SW) was used to determine the distributions of dependent variables, whose values were as follows: for marketable yield $\mathrm{SW}=0.83(p<0.001)$, for yield of turning fruits SW $=0.89(p<0.001)$, for yield of green fruit $\mathrm{SW}=0.93$ $(p \leq 0.003)$, for small fruits $\mathrm{SW}=0.75(p<0.001)$ and for diseased fruit SW $=0.87(p<0.001)$. Due to the lack of a normal distribution for the variables tested, a generalized linear model (GLM) for Poisson distribution with the log link function (Statistica for Windows $\mathrm{v}$ 12.5) was used to determine the relationship between the study period and cultivar and selected values of the yield structure.

\section{RESULTS AND DISCUSSION}

The study on the effect of ethephon on the yield structure of five tomato cultivars was conducted in 
Table 2. Results of generalized linear model (test of significance, Wald statistics) for the relationship between yield components (marketable yield, yield of turning fruits, mature green fruits and diseased fruits) across three years of vegetation and ethephon applications. Level of significance: $* * * p<0.001$

\begin{tabular}{lccc}
\hline Parameter & Year & $\begin{array}{c}\text { Ethephon } \\
(\mathrm{E})\end{array}$ & $\mathrm{Y} \times \mathrm{E}$ \\
\hline Marketable yield & $(\mathrm{Y})$ & $210.57^{* * *}$ & $100.84^{* * *}$ \\
Turning fruits yield & $17171.08^{* * *}$ & $234.92^{* * *}$ & $358.48^{* * *}$ \\
Mature-green fruits yield & $1217.03^{* * *}$ & $1374.50^{* * *}$ & 1.23 \\
Diseased fruits & $1920.31^{* * *}$ & $363.50^{* * *}$ & $339.72^{* * *}$ \\
\hline
\end{tabular}

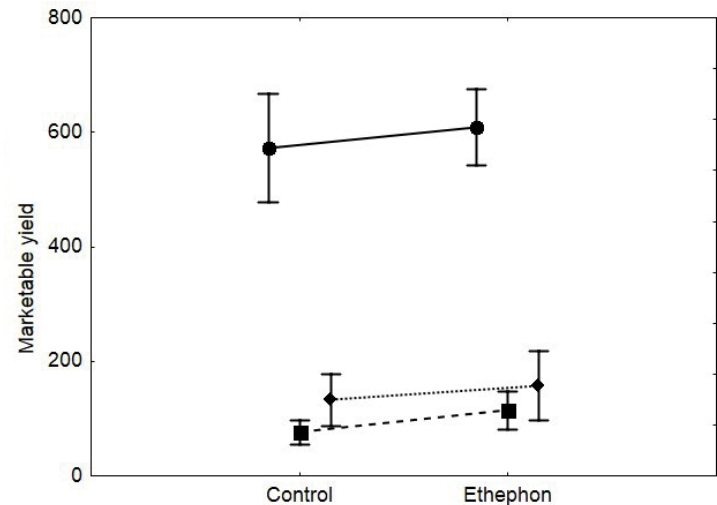

Figure 1. Marketable yield $\left(\mathrm{dt} \mathrm{ha}^{-1}\right)$ of tomatoes (mean for cultivars) treated and not treated (control) with ethephon for the three years of the investigation (circles -2009, squares - 2010, diamonds - 2011) (Bars indicate the deviation from arithmetic average value at 1.96 standard deviation)

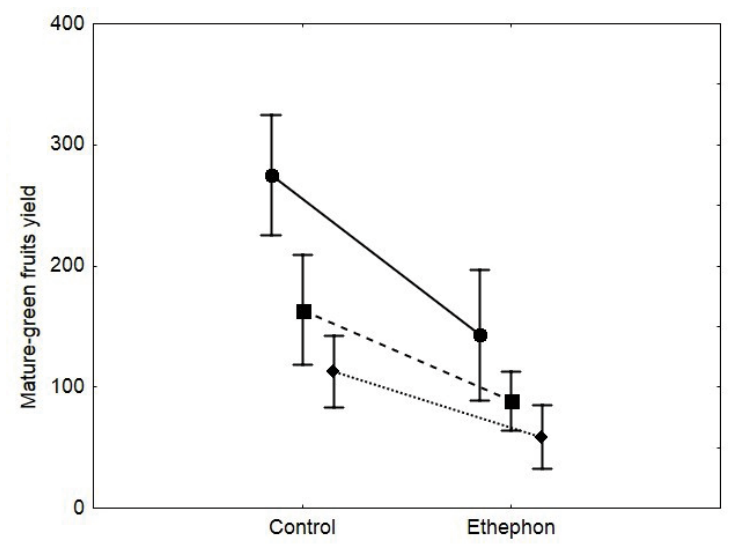

Figure 3. Yield of mature green fruits $\left(\mathrm{dt}^{\mathrm{h}} \mathrm{a}^{-1}\right)$ (mean for cultivars) of tomatoes treated and untreated (control) with ethephon for the three years of the investigation (circles - 2009, squares - 2010, diamonds - 2011) (Bars indicate the deviation from arithmetic average value at 1.96 standard deviation)

the years 2009-2011. The weather conditions during the growing seasons of that period had a decisive influence on tomato yield and its structure (Tabs 1 and 2, Figs 1-5).

The results of generalized linear model showed that the yield components (marketable yield,

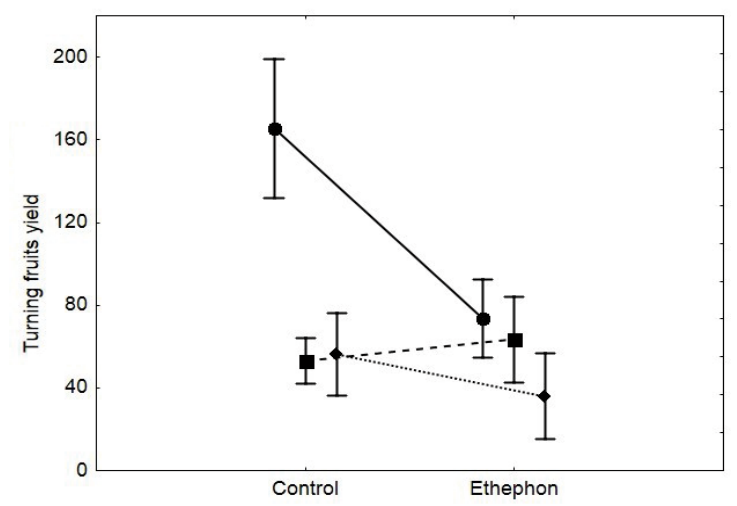

Figure 2. Yield of turning fruits $\left(\mathrm{dt} h \mathrm{~h}^{-1}\right)$ (mean for cultivars) of tomatoes treated and untreated (control) with ethephon for the three years of the investigation (circles - 2009, squares - 2010, diamonds - 2011) (Bars indicate the deviation from arithmetic average value at 1.96 standard deviation)

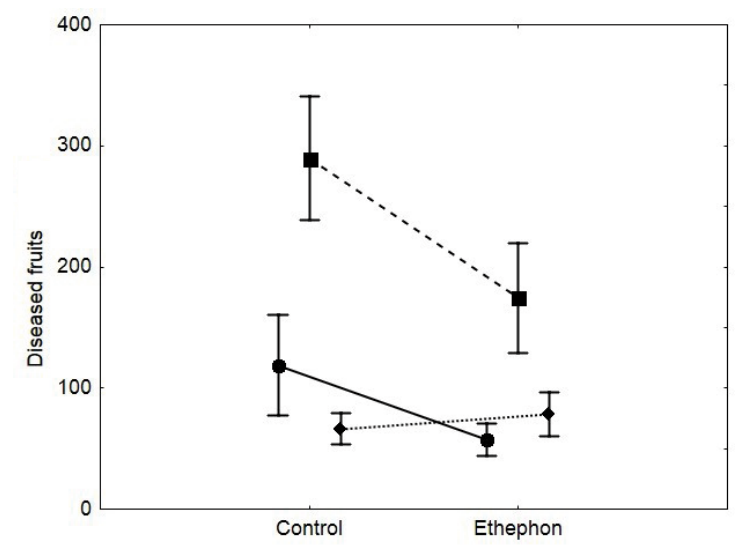

Figure 4. Diseased fruits (dt ha ${ }^{-1}$ ) (mean for cultivars) of tomatoes treated and untreated (control) with ethephon for the three years of the investigation (circles - 2009, squares - 2010, diamonds - 2011) (Bars indicate the deviation from arithmetic average value at 1.96 standard deviation)

yield of turning fruits, mature green fruits and diseased fruits) significantly depended on the year and ethephon application (Tab. 2). Marketable yield varied significantly in the years of the study (Fig. 1, Tab. 2). The highest marketable yield was noted in 2009, when the precipitation totals in July, 
August and September were somewhat lower than the long-term average, and the air temperature was higher (Tab. 1). In 2010 and 2011, the marketable yield was similar and significantly lower than in 2009, which may have been due to heavy and frequent rainfall in the period of fruit formation and ripening. Irrespective of weather conditions, in all the years of the study ethephon application was shown to have an effect on the marketable yield of the cultivars tested. This is also confirmed by Farag and Palta (1993), who found that ethephon application led to a greater proportion of marketable fruits as compared to the control. Ethephon had a particularly beneficial effect on yield structure in the years with unfavourable rainfall distribution. Gonzales (1999) confirms that ethephon application is not necessary in optimal climate conditions, but becomes essential in unfavourable conditions.

Following the spraying with ethephon, the secreted ethylene quickly stimulated the turning fruits to pass into the ripe phase, leading to an increase in marketable yield and a decrease in the number of turning fruits (Fig. 2, Tab. 2). Only in 2010 was the reverse reaction observed, which may have been linked to heavy rainfall in the days following the application of ethephon.

In all years of the study, following the application of ethephon, the yield of mature green fruits decreased significantly as compared to the control (Fig. 3, Tab. 2). Many authors emphasize that after ethephon application the average weight of fruits decreases (Logendra et al. 2004, Kenavy et al. 2008).

In 2009 and 2010, fewer diseased fruits were noted on the plots where ethephon was sprayed as compared to the control (Fig. 4, Tab. 2). Farag and Palta (1993) found no effect of ethephon on the proportion of non-marketable fruits (diseased or with spots) in the yield.

A study by Akinfasoye et al. (2011) showed that cultivars responded differently to agrotechnical factors in the same environment. The present study also showed significant differences in the response to ethephon application and its effect on yield structure in different cultivars (Tab. 3). In 2009, when the temperature and precipitation conditions were more favourable than in the other years of the study, significantly higher marketable yield was obtained for all the cultivars. The example of that year also shows the varied effect of ethephon application on different cultivars (Fig. 5). The impact of ethephon on marketable yield was noted for the late maturing Hubal cultivar. In the climate conditions of southern Poland, on the plantations where fruit ripening was not accelerated with ethephon, late cultivars produced poorer yields than early ones (Jędrszczyk et al. 2012). In the case of the remaining cultivars, with a shorter growing period, the effect of spraying was smaller or not significant. In 2010 and 2011, the marketable yield of all the cultivars tested was considerably lower than in 2009 (Fig. 5, Tab. 3). In those years, when the weather conditions were unfavourable to tomato growing (heavy and frequent rainfall during the fruit ripening period), the influence of ethephon on marketable yield was less pronounced.

The effect of ethephon application on the number of turning fruits can be seen in all the cultivars, especially in 2009 (Fig. 6, Tab. 3). Following the spraying with ethephon, most of the fruits entered the harvest maturity stage, resulting in significantly fewer turning fruits in comparison with the control. In 2010, when the distribution of precipitation during the fruiting period was particularly unfavourable to tomato, no impact of ethephon on the number of turning fruits was observed. In contrast, in 2011, when the rainfall distribution during this stage was somewhat more favourable than in 2010 (Tab. 1), we can see a similar relationship as in 2009 , but the differences are smaller.

Ethephon was found to significantly affect the yield of fruits grown to a typical size but still unripe for each of the cultivars in all years of the study (Fig. 7, Tab. 3). In general, higher yields of

Table 3. Results of the generalized linear model (test of significance, Wald statistics) for the relationships between yield components (marketable yield, yield of turning fruits, mature green fruits and diseased fruits) and three variables: crop year, ethephon application and cultivar (Poisson distribution, LOG link function). Level of significance: *** $p<0.001$

\begin{tabular}{|c|c|c|c|c|c|c|c|}
\hline Parameter & $\begin{array}{l}\text { Cultivar } \\
\text { (C) }\end{array}$ & $\begin{array}{c}\text { Ethephon } \\
\text { (E) }\end{array}$ & $\begin{array}{l}\text { Year } \\
(\mathrm{Y})\end{array}$ & $\mathrm{C} \times \mathrm{E}$ & $\mathrm{C} \times \mathrm{Y}$ & $\mathrm{E} \times \mathrm{Y}$ & $\mathrm{C} \times \mathrm{E} \times \mathrm{Y}$ \\
\hline Marketable yield & $1947.95 * * *$ & $144.25 * * *$ & $13482.16^{* * *}$ & $81.79 * * *$ & $1403.66^{* * *}$ & $63.61 * * *$ & $148.22 * * *$ \\
\hline Turning fruits yield & $234.83 * * *$ & $199.14 * * *$ & $1080.31 * * *$ & $47.31 * * *$ & $1002.11 * * *$ & $325.75 * * *$ & $301.09 * * *$ \\
\hline Mature-green fruits yield & $466.28 * * *$ & $1507.28 * * *$ & $1067.66^{* * *}$ & $989.73 * * *$ & $1156.43 * * *$ & $76.14 * * *$ & $730.05 * * *$ \\
\hline Diseased fruits & $111.79 * * *$ & $273.78 * * *$ & $3956.00 * * *$ & $374.07 * * *$ & $305.98 * * *$ & $272.38 * * *$ & $242.64 * * *$ \\
\hline
\end{tabular}




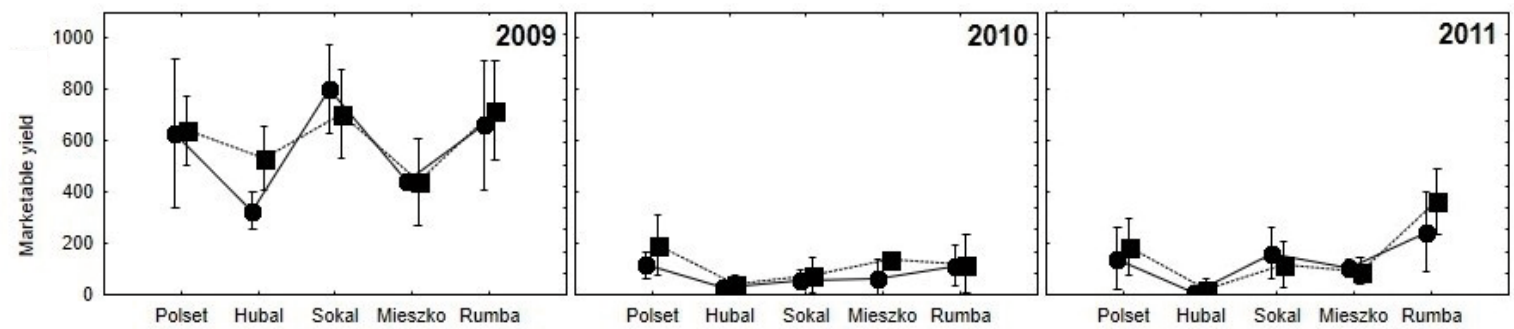

Figure 5. Mean marketable yield $\left(\mathrm{dt} \mathrm{ha}^{-1}\right)$ of tomato cultivars for the control (circles) and ethephon (squares) treatments for the three years of the investigation (Bars indicate the deviation from arithmetic average value at 1.96 standard deviation)

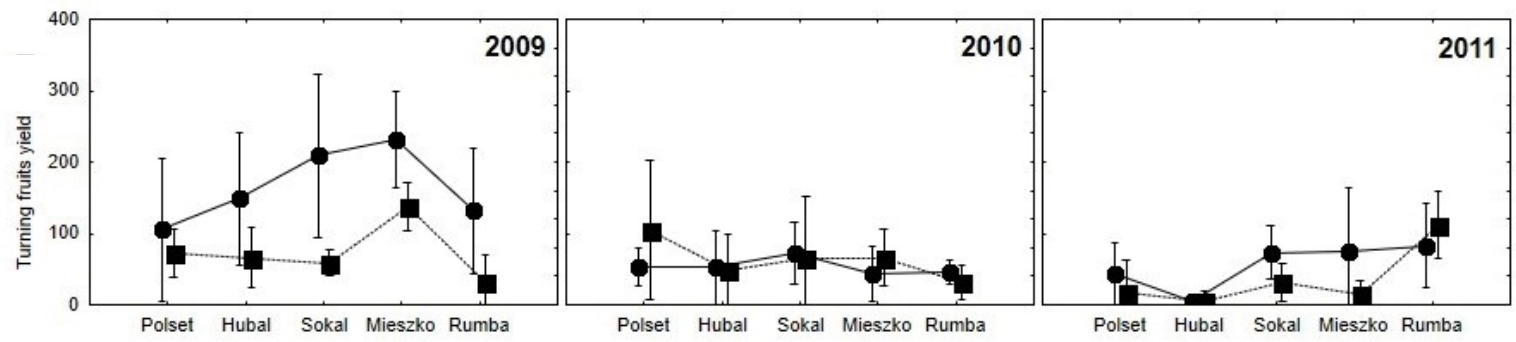

Figure 6. Mean yield of turning fruits $\left(\mathrm{dt} \mathrm{ha}^{-1}\right)$ of tomato cultivars for the control (circles) and ethephon (squares) treatments for the three years of the investigation (Bars indicate the deviation from arithmetic average value at 1.96 standard deviation)

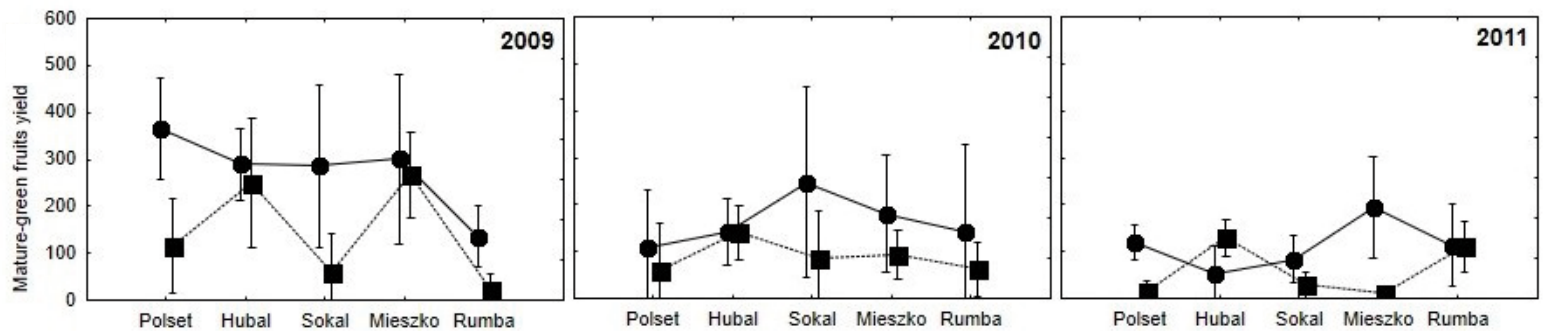

Figure 7. Mean yield of mature green fruits $\left(\mathrm{dt} \mathrm{ha}^{-1}\right)$ of tomato cultivars for the control (circles) and ethephon (squares) treatments for the three years of the investigation (Bars indicate the deviation from arithmetic average value at 1.96 standard deviation)

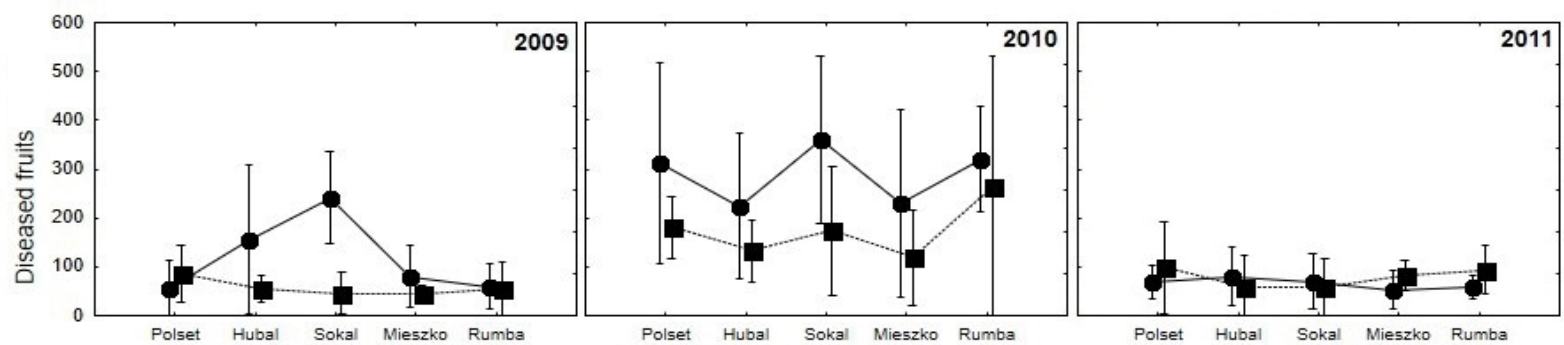

Figure 8. Diseased fruits of tomato cultivars $\left(\mathrm{dt} \mathrm{ha}^{-1}\right)$ for the control (circles) and ethephon (squares) treatments for the three years of the investigation (Bars indicate the deviation from arithmetic average value at 1.96 standard deviation)

mature green fruits were noted in the control plots. Such fruits may become fully ripe after harvest, during storage. The small yield of fully grown fruits produced by the sprayed plants may indicate more rapid ageing of the plant (withering leaves), which prevented small fruits from reaching their optimal size.
In the years 2009 and 2010, ethephon application had a beneficial effect on the health of the plantations (Fig. 8, Tab. 3). In 2010, all the cultivars tested had fewer diseased fruits in the plots where ethephon was applied. This effect was not noted in the year 2011. 


\section{CONCLUSIONS}

1. The yield structure of tomato depended significantly on weather conditions during the growing period in different years of the study, on the cultivar and on the use of ethephon.

2. Ethephon had a particularly beneficial effect on yield structure in the years with unfavourable distribution of precipitation.

3. Ethephon application in the years 2009 and 2010 had a beneficial effect on the health of tomato plants.

\section{FUNDING}

The research was carried out under grant no. 6ZR7 2008 C/07085, "Development and implementation of technology of tomato products with high lycopene content". Research task BZ 662/KWz $\mathrm{EO} / 09-11$.

\section{AUTHOR CONTRIBUTIONS}

E.J. - designed the experiment, performed measurements during vegetation and contributed to manuscript writing (50\%); B.S. - contributed to manuscript writing (30\%); R.K. - performed the statistical analysis; M.G. - performed measurements during vegetation.

\section{CONFLICT OF INTEREST}

Authors declare no conflict of interest.

\section{REFERENCES}

Akinfasoye J., Dotun A., Ogunniyan J., Ajayi E.O., 2011. Phenotypic relationship among agronomic characters of commercial tomato (Lycopersicum esculentum) hybrids. Am-Euras. J. Agron. 4(1): 1722.

Dhall R.K., Singh P., 2013. Effect of ethephon and ethylene gas on ripening and quality of tomato (Solanum lycopersicum L.) during cold storage. J. Nutr. Food Sci. 3(6): 1-7.

Dobromilska R., KuJath K., 2006. Influence of fruit ripening acceleration measures on flowering and fruiting of small-sized tomato. Acta Agrobot. 59(2): 191-198.
Farag K.M., PAlta J.P., 1993. Use of natural lipids to accelerate ripening and enhance storage life of tomato fruit with and without ethephon. HortTechnology 3(1): 62-65.

GonZales J.V., 1999. Use of ethylene (ethephon) in uniform ripening of processing (Lycopersicon esculentum) tomatoes in California. Acta Hort. 487: 179-182.

JęDrszczyk E., Skowera B., Kopcińska J., Ambroszczyk A.M., 2012. The influence of weather conditions during vegetation period on yielding of twelve determinate tomato cultivars. Not. Bot. Horti Agrobo. 40(2): 203-209.

Kevany B.M., Taylor M.G., Klee H.J., 2008. Fruitspecific suppression of the ethylene receptor LeETR4 results in early-ripening tomato fruit. Plant Biotechnol. J. 6: 295-300.

Liptay A., Jaworski C.A., Phatak S.C., 1981. Effect of tomato transplant stem diameter and ethephon treatment on tomato yield, fruit size and number. Can. J. Plant Sci. 61(2): 413-415.

Logendra L.S., Mun J.G., Gianfagna T.J., Janes H.W., 2004. Ethephon concentrates and advances harvest for limited cluster greenhouse tomato crops. HortScience 39(7): 1650-1651.

Moniruzzaman M., Khatoon R., Hossain M.F.B., Rahman M.T., Alam S.N., 2015. Influence of ethephon on ripening and quality of winter tomato fruit harvested at different maturity stages. Bangladesh J. Agril. Res. 40(4): 567-580.

OrŁowski M., Dobromilska R., Kujath K., 2005. The effect of methods accelerating fruit ripening on the yield of small-sized tomato. Folia Hort. 17(2): 61-69.

Payasi A., Sanwal G.G., 2010. Ripening of climacteric fruits and their control. J. Food Biochem. 34: 679710.

SAltveit M.E., 2005. Fruit ripening and fruit quality. In: Tomatoes. E. Heuvelink (ed.), CABI Publishing, Wallingford, UK: 145-159.

Saltveit M.E., 1999. Effect of ethylene on quality of fresh fruits and vegetables. Postharv. Biol. Technol. 15(3): 279-292.

Skowera B., JęDrszczyk E., Kopcińska J., Ambroszczyk A.M., KoŁton A., 2014. The effects of hydrothermal conditions during vegetation period on fruit quality of processing tomatoes. Pol. J. Environ. Stud. 23(1): 195-202.

Received November 17, 2016; accepted May 4, 2017 